DOI: https://doi.org/10.24297/jal.v10i0.8271

\title{
Multiple Draft Technique with Relevant Feedback to Improve Writing Skills: A Case Study
}

\author{
Dr Ch. Suvarna Ragini
}

Assistant Professor (English) Chaitanya Bharathi Institute of Technology Gandipet, Hyderabad

Telangana - 500075

swarnaragini@rediffmail.com

\begin{abstract}
Out of the four major skills, writing has become mandatory for academic success at secondary and tertiary levels. Writing has been taught for many years as a product rather than process during the students' formative years. In fact, there are many writing activities prescribed at the secondary level. However, most of the writing activities are neglected in the pretext of paucity of time or due to lack of interest among some teachers who consider evaluating the written assignments and giving feedback as laborious and peripheral tasks. As teachers of writing we are prone to expose our students to the rules of writing and grammar without developing their ability to express their ideas. Having identified the challenges faced by engineering students during writing tasks, the present study used the 'multiple draft strategy' with relevant feedback as an experimental method to explore its significance in developing the writing skills of the students at the tertiary level.
\end{abstract}

Keywords: Multiple Drafting, Constructive Feedback, Writing Ability.

\section{Introduction}

It is a common experience of most of our ESL teachers that whenever we correct the writing tasks of our students and give them feedback, it is either mostly unheeded or misinterpreted by the students. This is evident as similar types of errors are made by the learners repeatedly in spite of the teachers' correction and feedback. Most of us hope that our feedback will not only improve our student's writing but also help in their language development. The part that our feedback plays in such development is, however, still an open question. We should also investigate the component skills to be practiced while improving the writing skills. Therefore, the chief aim of the present study is to provide a framework to explore the relationship between teachers' feedback and ESL students' revisions through multiple drafting and writing development within an academic writing context.

\section{Background to The Study}

Out of all the four skills of language learning, writing is a difficult process for non-native speakers especially in our context where students come from multilingual back ground because they are expected to create written products that demonstrate mastery of certain elements in the target language. Dealing with written work with regard to giving comments on students' writing has been a challenging job for me. Writing in the academic context is an act which calls upon processes involving expression of ideas in a manner that satisfies ourselves and the readers. At the tertiary level our students are expected to write to fulfill functional purposes such as writing technical reports, resumes, applications for seeking jobs, covering letters etc., I find most of my students' written communication has many errors, both at the meaning level and in sentence constructions. Most of their expression of ideas is poor in spite of their fourteen years of previous exposure to learning English. As teachers, we feel it is our duty to see that our students produce a polished, edited and correct text. As the process of writing involves a complex set of operations, instructional contexts need to accommodate this complex procedure. Therefore, we have assumed that ultimately it is the feedback, given by the teachers on the students' writing scripts, that influences the students in their proficiency to a considerable extent. The present study 
addresses the use of "Multiple draft strategy" in developing the writing abilities of tertiary level students. The study is significant as the impact of this strategy on engineering students has rarely been explored by researchers. It would also focus on the issue as to how the students approach the writing process, view feedback and make revisions to their writing assignments.

\section{Literature Review}

In the present study we would like to focus our attention on the controversial issue whether error feedback helps L2 student writers to improve the accuracy and overall quality of their writing. One issue which has not been adequately examined is how explicit error feedback should be in order to help students to self-edit their texts. Researchers like Ericksen, 1990; Truscott 1996; still continue to express their doubt regarding the effectiveness of teachers' feedback on improving the learner's writing ability. We believe that there are many elements and characteristics of student texts that determine their overall quality. As experienced L2 writing instructors we would not argue that the number of linguistic errors made by students represent the texts' merits or a student's ability. However, the study is a move towards the belief that Constructive feedback and the revision process do have a positive effect on the improvement of students' writing ability.

\section{The Relevance of Constructive Feedback}

As language teachers our jobs require us not only to evaluate our students' writing but also to be able to justify our evaluations. A good feedback should try to stimulate a response and inspire the student to have a continuous dialogue on the aspects of his/her performance. Therefore, we have to find out how helpful students find our feedback and how it might be improved in future. If we encourage students to rethink what they have written and to revise their drafts with necessary changes, perhaps we can expect improvement in their writing skills. In the present study we have based our framework on Figley Faigley and Witte's (1981) taxonomy of revisions to be able to give constructive feedback.

\section{Faigley and Witte's (1981) Taxonomy of Revisions}

Faigley and Witte's (1981) taxonomy of revisions was used to identify the types of revisions to be made to the students writing assignments. The taxonomy consists of two major categories which are (1) Surface changes and (2) Text-based changes. There are six specific types of revisions in each of these broad categories. Revision types were identified based on a taxonomy that discriminates between the two types of changes

1. Surface changes do not affect the meaning and no new information is brought to the text. They relate to formal changes such as spelling, punctuation, formatting, tenses, number and morphological changes. They also paraphrase the original concepts in the text by making them implicit or explicit, without altering meaning. All information is recoverable by inferencing.

2. Text based changes enable simple adjustments or elaborations of existing text. They do not affect the overall summary or direction of the ideas in the text. They may involve the use of cohesive ties causing sentence sequences to be understood as consistent and parallel to an effectively connected discourse.

\section{Methodology}

The study was carried out at Chaitanya Bharathi Institute of Technology at Hyderabad. The researcher, who is a faculty member there, experimented with multiple draft technique with relevant feedback while teaching a credited course titled "Professional Communication in English" to a class of 60 B.Tech. students. Since it was a course comprising all four major language skills, only two classes could be devoted towards teaching writing skills. The writing classes were conducted twice a week for fifty minutes each focusing on teaching and improving writing skills of the students. 
During the first week, the students were asked to write an appeal letter to fellow students asking them to volunteer to take literary classes. In their letter they were supposed to give reasons as to why literary classes should be held what students can do and why they should do it. As a part of second activity, they were asked to write an essay of about 3 paragraphs on the topic "Minimize pollution and save Mankind". The compositions written as first drafts were corrected by the researcher and the written feedback was given on their scripts. The students were asked to revise their compositions based upon the teachers' feedback and write the compositions again for the same tasks as their final drafts.

\section{Discussion}

The students first looked at the corrections and read the comments in the margin. They reported that they made very systematic use of feedback provided on their written drafts which helped them make necessary revisions to their final drafts taking all the corrections into consideration. At the end they were convinced that feedback had been the factor which had helped them the most in improving their final drafts.

Using Faigley and Witte's (1981) taxonomy of revisions, each revision made to the first and second drafts of the compositions was categorized as either a surface change or meaning change. The unit of analysis was either lexical, phrasal, clausal, sentential, or multi sentential. On the first drafts of their compositions for example two students made nearly fourteen changes which were at the meaning level and nearly nineteen changes which were at the surface level. A few other students made about ten surface level (formal) changes whereas another few students made only six formal changes on their first drafts of compositions based upon the teacher's feedback.

Despite the high percentage of surface-changes, students in the current study were able to make some globallevel changes to their written work. While the current study did not find students making more meaning-level changes than surface-level changes, the study also indicated that students did use teacher's feedback to influence their revisions.

Example of the revisions made to improve sentence structures:

\begin{tabular}{|c|c|c|c|}
\hline S.No. & Draft 1 & Feedback points & Draft 2 \\
\hline 1. & $\begin{array}{l}\text {....mosquitoes are so } \\
\text { strong that they are not } \\
\text { even dying to DDT,... }\end{array}$ & $\begin{array}{l}\text { Replace the phrase "not } \\
\text { even dying..." with "have } \\
\text { become resistant" }\end{array}$ & $\begin{array}{l}\text {..... mosquitoes have } \\
\text { become resistant to } \\
\text { DDT... }\end{array}$ \\
\hline 2. & $\begin{array}{l}\text { When it rains the roads } \\
\text { fill with.... }\end{array}$ & Use passive voice & $\begin{array}{l}\text { The roads are filled with } \\
\text { drainage water... }\end{array}$ \\
\hline 3. & $\begin{array}{l}\text {....there will bea water } \\
\text { logging .... }\end{array}$ & $\begin{array}{l}\text { Do not use an article } \\
\text { before an uncountable } \\
\text { noun }\end{array}$ & $\begin{array}{l}\text { There will be water } \\
\text { logging on the road }\end{array}$ \\
\hline 4. & $\begin{array}{l}\text { Pollution causes serious } \\
\text { problem on earth. It may } \\
\text { be as destructive as } \\
\text { world war if we do not.... }\end{array}$ & $\begin{array}{l}\text { Join the two ideas using } \\
\text { "furthermore" }\end{array}$ & $\begin{array}{l}\text {...serious problem on } \\
\text { earth. Furthermore, it } \\
\text { may be as... }\end{array}$ \\
\hline 5. & $\begin{array}{l}\text { This may cause huge } \\
\text { damage to mankind. The } \\
\text { measures that can be } \\
\text { taken to decrease } \\
\text { pollution. }\end{array}$ & $\begin{array}{l}\text { Begin with 'therefore' } \\
\text { before } \\
\text { measures. }\end{array}$ & $\begin{array}{l}\text { Therefore, the measures } \\
\text { that can be taken. }\end{array}$ \\
\hline
\end{tabular}


Sample of the total revisions made by a student in his first and final drafts

\begin{tabular}{|c|c|c|}
\hline Type of errors & $\begin{array}{l}\text { First draft (D1) } \\
\text { No. of revisions }\end{array}$ & $\begin{array}{l}\text { Final Draft (D2) } \\
\text { No. of revisions }\end{array}$ \\
\hline Surface-level & & \\
\hline Spelling & 4 & 2 \\
\hline Capitalization & 5 & - \\
\hline Tense & 2 & 4 \\
\hline Abbreviation & 9 & - \\
\hline Punctuation & 1 & 1 \\
\hline Morphological & 4 & 3 \\
\hline Meaning-level & 8 & 2 \\
\hline Clarification & 3 & 3 \\
\hline Word expression & 4 & - \\
\hline Repetition & 5 & 1 \\
\hline Cohesive devices & 4 & - \\
\hline $\begin{array}{l}\text { Organization } \\
\text { Conclusion }\end{array}$ & 4 & - \\
\hline Total & 53 & 16 \\
\hline
\end{tabular}

\section{Findings}


The results of the study indicated that the most common type of revisions made to their compositions were surface-level changes that could alter the surface structure without deleting the old information from the written text. Though the meaning level changes made to their compositions were less in number, they did affect the compositions in improving the organizational skills. Out of the surface-level changes the meaning preserving changes accounted for less than formal changes which could paraphrase and re-word concepts present in the initial drafts of the compositions.

The researcher analyzed the students' essays in detail, categorizing the types and sources of revisions made according to Faigley and Witte's (1981) taxonomy of revisions, evaluating the first and final drafts of the students' essays. While the majority of revisions that students made were surface-level revisions, the changes they made as a result of teacher feedback were more often meaning-level changes than those revisions they made on their own. Results of the study indicated that systematic feedback given by the teacher positively affected the students' revision types and quality of texts. It was further found that writing multiple drafts with the support of constructive teacher feedback resulted in overall essay improvement.

\section{References:}

1. Austin, J.L. (1962). How to do things with words. Oxford, Oxford University Press.

2. Ericksen Hill, Carolyn. (1990). Writing from the Margins. Oxford: Oxford University Press.

3. Faigley and Witte, S. (1981). Analyzing revision. College Composition and Communication. 32, 400-414.

4. Truscott, J. (1996). The case against grammar correction in L2 writing classes. Language Learning. 46 (1), 327-369.

5. Zamel, V. (1985). Responding to student writing. TESOL Quarterly, 19 (1),79-101. 